\title{
Economie (en) bedrijven - over de bedrijfseconomie als discutabel, spannend en eigen-aardig onderdeel van de economische wetenschappen
}

Citation for published version (APA):

Schreuder, H. (1985). Economie (en) bedrijven - over de bedrijfseconomie als discutabel, spannend en eigen-aardig onderdeel van de economische wetenschappen. Van Gorcum. https://doi.org/10.26481/spe.19850906hs

Document status and date:

Published: 06/09/1985

DOI:

10.26481/spe.19850906hs

Document Version:

Publisher's PDF, also known as Version of record

Please check the document version of this publication:

- A submitted manuscript is the version of the article upon submission and before peer-review. There can be important differences between the submitted version and the official published version of record.

People interested in the research are advised to contact the author for the final version of the publication, or visit the DOI to the publisher's website.

- The final author version and the galley proof are versions of the publication after peer review.

- The final published version features the final layout of the paper including the volume, issue and page numbers.

Link to publication

\footnotetext{
General rights rights.

- You may freely distribute the URL identifying the publication in the public portal. please follow below link for the End User Agreement:

www.umlib.nl/taverne-license

Take down policy

If you believe that this document breaches copyright please contact us at:

repository@maastrichtuniversity.nl

providing details and we will investigate your claim.
}

Copyright and moral rights for the publications made accessible in the public portal are retained by the authors and/or other copyright owners and it is a condition of accessing publications that users recognise and abide by the legal requirements associated with these

- Users may download and print one copy of any publication from the public portal for the purpose of private study or research.

- You may not further distribute the material or use it for any profit-making activity or commercial gain

If the publication is distributed under the terms of Article $25 \mathrm{fa}$ of the Dutch Copyright Act, indicated by the "Taverne" license above, 


\section{ECONOMIE(EN) BEDRIJVEN}

Over de bedrijfseconomie als discutabel, spannend en eigen-aardig onderdeel van de economische wetenschappen

\section{REDE}

in verkorte vorm uitgesproken bij de aanvaarding van het ambt van hoogleraar in de Bedrijfseconomie aan de

Rijksuniversiteit Limburg

op vrijdag 6 september 1985

door

Dr. H. Schreuder

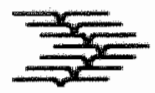

Van Gorcum, Assen/Maastricht, 1985 



\title{
ECONOMIE (EN) BEDRLIVEN
}

\section{Over de bedrijfseconomie als discutabel, spannend en eigen-aardig onderdeel van de economische wetenschappen}

\author{
Prof. dr. H. Schreuder
}

\section{Inleiding}

Bedrijfseconomie is een discutabel vak; er word althans veel en vaak over gediscussieerd. Vanmiddag wil ik enkele aspecten van deze discussie met u doornemen.

Het centrale thema van mijn rede wordt weergegeven door de titel ervan. Bij nadere beschouwing blijkt echter dat er niet sprake is van éen striktomschreven titel: er zijn drie vlaggen die de lading dekken. Evenzo zijn er tenminste drie manieren waarop tegen de bedrijfseconomie kan worden aangekeken, namelijk als:

1. Economie bedrijven: in deze visie is de bedrijfseconomie een deelwetenschap van de economie. Zij houdt zich dus bezig met keuzeproblemen onder schaarsteverhoudingen. Daarbij richt zij zich voomamelijk op de keuzeproblemen die zich binnen bedrijven voordoen', voor zover deze als een economisch probleem geformuleerd kunnen worden. De grensafbakening tussen algemene en bedrijfseconomie is dan een kwestie van doelmatige arbeidsverdeling.

2. Economie en bedrijuen: in deze optiek zijn de economische wetenschap en de praktische bedrijfsproblematiek twee tamelijk losstaande gebieden. De nadruk ligt sterk op de problemen waarmee bedrijuen geconfronteerd worden. In hoeverre de economie daarbij behulpzaam kan zijn, valt steeds afzonderlijk te bezien. De conomic neemt derhatve geen voorkeurspositie in temidden van de overige wetenschappen die bij de bestudering van bedrijfsproblemen van belang kumnen zijn. $\mathrm{Er}_{\mathrm{r}}$ wordt als het ware per probleem bezien welk samenstel wan wetenschap-

\footnotetext{
1 'Voomamelijk', aangezien zij ook sommige verschijnesen bestudect, die rechtsiecks relevant zin woor de economische keuzeproblemen binnen bedrijven, zoals de werking van do vermogensmarkt. Er word her niet ingegan op het onderscheid tussen bedrijwen, onderne. mingen en organisaties. Zue darwoor Bouma (1982). De term bedrif wordf hior ir nume zin gehanteerd gamelijk als (dat deel wan) exn organisatie watrin zich keuzeproblemen war economische ard woordoen
} 
pen relevante inzichten kan aabieden. Zodoende wordt van de aanvang af gestreefd naar een multi- of liefst interdisciplinaire aanpak van bedriffsproblemen.

3. Economieèn bedrijuen: deze derde beschouwingswijze gaat ervan uit dat er niet é̉n economische wetenschap is die op strikte wijze omschreven kan worden. 'Economics is what economists do'. Het werk van algemeen-economen en van bedrijfseconomen vertoont weliswaar overlappingen en raakvlakken, maar anderzijds ook sterke verschillen. ${ }^{2}$ In deze variant heeft de bedrijfseconomie weliswar een stevig economisch fundament, maar is overigens op een zodanig eigen wijze ontwikkeld met name voor wat betreft haar probleemkeuzen en de integratie van inzichten uit andere disciplines - dat gesproken kan worden van een tamelijk verzelfstandigd vakgebied. Het is juist in deze eigen benadering van bedrijfsproblemen - vanuit een economisch vertrekpunt, maar met aanwulling door en, 20 mogelijk, integratie van inzichten uit andere disciplines - dat de bedrijfseconomie haar grootste praktische relevantie bereikt.

Deze drie visies op thet vakgebied bedrijfseconomie verschillen voornamelijk in twee opzichten:

- de relatie tussen de bedrijfseconomie en de algemeen-economische wetenschap; en

- de relatie tussen de bedrijfseconomie en de praktijk.

Het zijn deze twee aspecten van de discussie die ik vanmiddag wil becommentariëren. Daarbij ligt de nadruk op het eerstgenoemde aspect. Overigens kies ik mijn uitgangspunt nadrukkelijk in de bedrijfseconomie zelf: in haar historische ontwikkeling en huidige situatie. Nadat deze in vogelvlucht beschreven zijn, kom ik toe aan de behandeling van de twee genoemde aspecten.

\section{De ontwikkeling van de bedrijfseconomie}

De bedrijfseconomie is in ons land niet ontstaan als afsplitsing van de algemene economie, maar veeleer als reactie op een in de praktijk gevoelde behoefte. Het begin van thet hoger onderwijs in de bedrijfseconomie kan in ons land worden gedateerd op 6 januari 1909 wanneer J.G.Ch. Volmer zijn

2 Overigens is ook binnen de algemene economie resp. de bedrijfseconomie sprake van een stekk produktdilierentiatie.

'Dezk paragrafl is in sterke mate gebaseerd op Muysken en Schreuder (1985). 
ambt aanvaardt als hoogleraar in de bedrijfsleer en het boekhouden aan de Technische Hoogeschool te Delfi. In 1913 gaan de poorten van de Nederlandsche Handels-Hoogeschool te Rotterdam open, terwijl in 1921 een handelsfaculteit wordt toegevoegd aan de Gemeentelike Universiteit te Amsterdam. Inmiddels is in 1984 te Maastricht de zesde economische faculteit in Nederland officieel van start gegaan, terwijl bedrijfseconomie behalve aan de economische opleidingen ook wordt onderwezen in bijv. juridische en bedrijfskundige faculteiten.

Er zijn in de afgelopen vijfenzeventig jaar grofweg twee soorten strategieën gevolgd voor de ontwikkeling van het vakgebied. In navolging van Pantin (1968) en Van Rossum (1985) zal ik deze strategieën aanduiden als resp. de "restrictieve" en de "niet-restrictieve'. Hieronder zal ik trachten de belangrijkste verschillen tussen deze twee strategieën kort samen te vatten. Figurur 1 geeft met enkele steekwoorden een overzicht.

Figur 1. Restrictieve versus niet-restrictieve strategiedn in de bedrifseconomie

\begin{tabular}{|c|c|c|}
\hline & Restrictief & Niet-restrictief \\
\hline Dommante orièntate & Economisch-theoretisch & Praktisch \\
\hline Werkwijze & Wnil. deductier & Vol. inductief \\
\hline Reikwijdte & $\begin{array}{l}\text { Tijd en plaats- } \\
\text { onathankelijk }\end{array}$ & $\begin{array}{l}\text { Tijd-en plaats- } \\
\text { athankelijk }\end{array}$ \\
\hline $\begin{array}{l}\text { Relatie tot (algemeen) } \\
\text { ecomomische theorie }\end{array}$ & Verwant & Afstandelijk \\
\hline Relatie tot praktijk & Voorschrijuend" & $\begin{array}{l}\text { Beschrijuend en } \\
\text { generaliserend }\end{array}$ \\
\hline $\begin{array}{l}\text { Relatie tot } \\
\text { andere } G M W\end{array}$ & Afstandelijk & $\begin{array}{l}\text { Integrerend } \\
\text { (waar nodig) }\end{array}$ \\
\hline $\begin{array}{l}\text { Voorbeeld in } \\
\text { Wroegere Ned. } \\
\text { bedriffseconomie }\end{array}$ & $\begin{array}{l}\text { "Amsterdamse School" } \\
\text { (Lumperg) }\end{array}$ & $\begin{array}{l}\text { 'Rotterdamse } \\
\text { benadering" } \\
\text { (Polak e.a.) }\end{array}$ \\
\hline Huidig voorbeeld & Pure theory of rinance & Manageriall binance \\
\hline
\end{tabular}

* Namelijk: waar mogelijk, rationeel gedrag voorschrijyend ten anzien wan het economische aspect van keuzeproblemen. 
De restrictieve strategie kiest een nauwe afbakening van het werkterrein. Daarbij worden overwegend theoretische criteria aangelegd. Wat bedrijfseconomie is, valt af te lejden uit de economische theorie. Enkele centrale economische begrippen fungeren als grensafbakeningen van het (bedrijfs) beconomisch arbeidsweld. Deze begrippen vormen ook de uitgangspunten (axioma's) van de economische theorievorming. Van daaruit wordt als het ware naat de werkelijkheid toe geredeneerd (axiomatisch-deductief) en wel langs de weg van de afnemende abstractie. Idealiter word ook de ongekeerde weg bewandeld: confrontatie van de werkelikheid met de theorie(ën). Deze weg wordt echter aanzienlijk minder frequent begaan (vgl. Blaug, 1980, p. 256). Het wereldbeeld dat aan deze strategie ten grondslag ligt, wordt gekenmerkt door het tamelijk onveranderlijk optreden van enkele dominante verklaringsfactoren op het gekozen werkterrein. De strategie levert een bedriffseconomische theorie op van een nogal hoog abstractieniveau, warin veelvuldig een beroep moet worden gedaan op de ceteris paribus clausule om verstorende invloeden op het verklaringsschema uit te sluiten.

In de niet-restrictieve strategie geeft daarentegen niet de theorie, maar de praktijk de doorslag bij de afbakening van het arbeidsveld. Wat bedrijfseconomie is, wordt hoofdzakelijk bepaald door de perceptie wan bedrijfsproblemen in de praktijk. Men komt dan al gauw uit op het centrale probleem, het besturingsprobleem, van het bedrijf. Aanhangers van de niet-restrictieve strategie zijn veelal onder de indruk van de complexiteit en de veranderlijkheid van bedrijfsproblemen. Geconfronteerd met die complexiteit ligt het woor de hand de wetenschappelijke arbeid te laten aanvangen met het in kaart brengen van het arbeidsveld (beschrijving en classificatie) om van daaruit hopelijk te geraken tot theorievorming (inductie). Geconfronteerd met de veranderlijkheid van de praktijk ligt het voor de hand deze nauwlettend te volgen om bedrijfseconomische kennis actueel te houden. Idealiter worden de inductief verkregen theorieen vervolgens getoetst aan de werkelijkheid. Doorgaans is echter slechts zelden sprake van echte theorievorming en -toetsing.

Oplettende lezers/toehoorders zullen hebben opgemerkt dat de restrictieve strategie een aantal overeenkomsten vertoont met wat ik in de inleiding "economie bedrijen" heb genoemd. De economische theorie staat voorop; de toepassing c.q. de ontwikkeling daarvan is dan in de bedrijfseconomie voornamelijk gericht op keuzeproblemen binnen bedrijven. Het is niet verwonderlijk dat juist deze strategie de beste aansluiting laat zien met de werkwijze van algemeen-economen. De niet-restrictieve strategie is verwant met de visie die ik 'economie en bedrijven' heb genoemd. Hier staat de praktijk voorop; het is een empirische vraag in hoeverre de 
economie behulpzam kan zijn bij de bestudering van bedrijfsproblemen. Deze strategie geeft de beste aansluiting met hetgeen in ons land bekend is komen te staan als 'bedrijskunde'?

Ik heb tot dusverre betoogd dat beide strategieen zijn gevolgd in de (Nederlandse) bedrijfseconomie. Daarbij heeft de restrictieve strategie geleid tot een reservoir van theoretische inzichten, maar slechts in enkele gevallen tot resultaten die alom als praktisch relevant worden erkend. ${ }^{6} \mathrm{De}$ niet-restrictieve strategie heeft daarentegen gelleid tot een fonds van praktijkkennis. Slechts in tuitzonderingsgevallen is deze kennis zodanig gesystematiseerd en gegeneraliseerd dat er van theorievorming kan worden gesproken. Als gevolg van deze ontwikkeling is de aansluiting tussen theoretische inzichten en praktijkkennis helaas mager. Er bestaat zelfs een zekere spanning tussen beide oriëntaties in de bedrijfseconomie. Dit blijkt dus niet alleen een discutabel, maar ook een spannend vak te zijn!

De spanning in het wak is in het verleclen nog wel eens hoog opgelopen. Zoals figuur 1 reeds aangaf, stonden daarbij in Nederland een "Amsterdamse School', gesticht door Limperg, en een 'Rotterdamse benadering' (zonder duidelijk centrale figuur) tegenover elkaar. De 'Amsterdamse School' propageerde een restrictieve strategie en beschouwde de bedrijfseconomie als een deelwetenschap van de economie. De theoretische oriëntatie was sterk geprononceerd. De 'Rotterdamse benadering' oriënteerde zich sterker op de praktijk. Zij incorporeerde, waar nodig, inzichten uit andere disciplines indien praktijkproblemen daartoe aanleiding gaven.

Tegenwoordig is cleze spanning in het vak niet zozeer geografisch bepaald, maar terug te vinden in de deeldisciplines van het vak zelf. In vrijwel alle onderdelen van de bedrijfseconomie vindt men enerzijds toepassingen en uitwerkingen van economische theorieën en anderzijds generalisaties van in de praktijk opgedane inzichten. Tussen beide bestaat onvoldoende aansluiting. Daarbij komt nog dat zich in de loop der tijd nieuwe specialisaties in de bedrijfseconomie hebben ontwikkeld en dat in de verschillende specialisaties in uiteenlopende mate gebruik wordt gemaakt van de resulta-

"De visie die $\mathrm{k}$ in de inleiding aranduide als "economiech bedrijen" neom hierbij een tussenpositie in. In deze visie wordt de economische theoric, war mogetijk, gelkozen als wertrekpunt voor de bednifseconomische analyse. Tevens word gestreefd natr ean geintegreerde benadering van bedrifsproblemen op basig van de economische theorie. Waar nodig. wordt echter nict geschroomd de conomische inzichten aan to vullen met die wit andere disciplines. Confrontatie van het economisch-theoretisch analysekader met actuele bedrijfsproblemen lat dian zien op welke punten zulke aanvulling nodig is.

6 Twe van zulke voorbeelden zijn (a) de modellen van aandelen-n optiewardering uit de moderne Inancieringstheorie en (b) sommige actuele waarde-stelsels uit de bericht gevingstheorie.

Z Zie ook Spronk (1984) en Schreuder (1985). 
ten wan andere wetenschappen. Voor de integratie van de bedrijfseconomische deeldisciplines ontbreekt een alom aanvaard kader. Al met al ervaren velen dit proces van differentiatie als één van fragmentatie. Pleidooien voor een heroriëntatie van de bedrijfseconomie steken in toenemende mate de kop op.

\section{Naar een heroriëntering van de bedrijfseconomie?}

Discussies over de noodzaak tot heroriëntering van de bedrijfseconomie zijn bijna even oud als het vak zelf. Met deze voorafgaande historische relativering will ik een kort overzicht geven wan enkele recente bijdragen alan deze discussie. Er is hier slechts plaats voor enkele hoofdlijnen.

Bouma (1966) en andere Groningse auteurs hebben er sinds het midden van de jaren zestig bij voortduring op gewezen dat in de restrictieve variant van de bedrijfseconomie veelal uitgegaan wordt van te beperkende veronderstellingen omtrent het menselijk gedrag. Met name de veronderstelling van onbegrensde rationaliteit was het mikpunt van hun kritiek. Zij wensten deze wervangen te zien door Simon's concept van 'begrensde rationaliteit':

"The capacity of the human mind for formulating and solving complex problems is very small compared with the size of the problems whose solution is required for objectively rational Behavior in the real world" (Simon, 1967, p. 198).

Als gevolg daarvan is menselijk gedrag:

' intendedly rational, but only linitedly so'

(Simon, 1961, p. XXIV).

Door Bosman (1977) wordt deze kritiek onderschreven. Hij voegt er nog een aantal bezwaren tegen de traditionele bedrijfseconomie aan toe:

- zij heeft haar problemen tezeer gekozen vanuit de visie van het topmanagement en heeft als doeleinden van de organisatie tezeer slechts die van de topleiding in de beschouwing betrokken;

- zij heeft de structuur van de organisatie als gegeven aanvaard en deze dus niet trachten te verklaren;

- zij heeft de problematiek van de coördinatie (dat wil zeggen de onderlinge afstemming van beslissingen in de organisatie) verwaarloosd;

- zij is normatief in de zin van niet-waardevrij.

* Zie biju, hun reeks antikelen in Economisch-Statistische Berichten in de tweede helft van de jaren zeventig. 
Bosman schetst de contouren van een 'andere' bedriffeconomie. Daarbij streeft hij naar de volgende doeleinden:

a. versterking van de coördinatie tussen de verschillende beslissingen die in organisaties worden genomen; en

b. verklaring van het gedrag van organisaties, zoals dat in de werkelijkheid waaneembaar is (Bosman, 1977, p. 238).

In zijn ontwerp wordt uitgegaan van locale beslissingen in organisaties. Hij prefereert een 'bottom up'-benadering van de structuur van organisaties en legt daarbij sterk de nadruk op het coördinatieprobleem. Planning speelt bij deze coördinatie een grote rol (zie ook Van Helden e.a. "1980; Bosman, 1980). Tot slot is het goed erop te wijzen dat Bosman niet pleit voor een 'andere' bedrijfseconomie buiten het gebruikelijke arbeidsveld van de economie:

'De roep om een inter- en/of multidisciplinaire benadering van problemen toont an dat men de monodisciplinaire benadering niet adequat acht en dat het kenobject als hulpiniddel voor de afbakening als niet walide terzijde dreigt te worden geschoven. Ik zou dat latsto betrewen. Het kenobject is een middel voor de keuze van het uitgangspunt. Het in de economie gebrukelijke kenobject, de allocatie van schaarse, alternatief namwendbart middelen, suit een inter- of multidisciplinaire benadering, hoe dan ook gedefinieend, niet uit' (Bosman, 1980 , pp. $228 \cdot 229$ ).

Veel aandacht heeft ook een beschouwing van Traas (1981) gekregen. Ook hij houdt vast aan het kenobject van de economie, maar wenst de rol hiervan teruggebracht te zien tot vertrekpunt van de bedrijfseconomische analyse. Het economisch aspect dient dan in samenhang met andere aspecten, die een rol spelen in het besluitvormingsproces, geanalyseerd te worden. Traas noemt drie bezwaren die zijn gerezen tegen de klassieke bedrijfseconomie:

1. Zij is niet in staat gebleken 'harde' conclusies op te leveren. Men zal zich tevreden moeten stellen met:

¿., conchusies warvan de geldigheid nat tijo on plats beperk is, die minder betrouw. baar zijn, die niet noodzakelijk wolledig en logisch-sluitend passen in een axiomatusch opgebouwd theoretisch systeem en warin tenslote ook wor subjoctieve diementen plats is (Traas, 1981, p. 149).

2. In de bedrijfseconomie bestaat vaak geen direct verband tussen verkre. gen kennis die een verklaring geeft van de samenhang van bedrijfseconomische verschijnselen en de kennis die nodig is ten behoeve wan richtlijnen of normen woor praktische toepassing. 
3. Economische subjecten staan vaak niet 'neutraal' tegenover gedragsal-ternatieven. Psychologische, sociale, thische en andere elementen spelen een rol. Daardoor verkrijgt een geisoleerde economische benadering al gauw een sterk kunstmatig karakter.

Traas pleit voor een herorièntering van de bedrijfseconomie op het bestuurlijke' vraagstuk. Het zwaartepunt van de bedrijfseconomische probleemstelling blijft het economisch aspect, maar:

‘...onderdeel van de problemstelling wordt ook, thoe in een bedrijfshuishouding als ecow nomische doelorganisatie de besturing dient plats te vinden en aan het beleid inhoud dient te worden gegeven vamuit een 'integrale" beschouwingswijze' (Traas, 1981, p. 151)

Tussen Bosman en Traas blijkt overeenstemming te bestaan omtrent: (a) het vasthouden aan het economisch uitgangspunt van de bedrijfseconomische analyse en (b) de noodzaak tot verdere uitwerking van de bedrijfseconomie in de richting van het bestuurlijke vraagstuk (de coördinatie van het besluitvormingsproces en van beslissingen) zoals zich dat in de praktijk voordoet. Bij de concrete invulling daarvan vertoont hun aanpak overigens tamelijk grote werschillen, die hier echter minder terzake doen.

Overziet men de reacties op deze voorstellen en de verdere discussie", dan vallen daarin gemakkelijk de restricrieve en niet-restrictieve tendensen te onderscheiden. Sommigen wensen nadrukkelijk vast te houden aan de 'harde' economisch-theoretische kern van de bedrijfseconomie (bijv. Duffhues, 1985) resp. daarnaar terug te keren (bijw. Van der Zwan, 1983). Incorporatie van met name gedragswetenschappelijke elementen is in deze visie ongewenst in zoverre dat daardoor de aandacht wordt afgeleid van de economische analyse. Anderen (waaronder Feenstra en Van de Poel, 1985) achten een dergelijke uitbouw nu juist essentieel om de bedrijfseconomie een groter realiteitsgehalte te geven. Tot slot moet worden vermeld dat sommige bijdragen aan de discussie de hoop of zelfs de verwachting uitspreken dat de opkomst van de bestuurlijke informatiekunde een nieuw integratiekader voor de bedrijtseconomie kan bieden (vgl. Oonincx, 1983 en Eyzenga, 1984).

* In de verdere discussic hebben zich onder meer gemengd: Bindenga (1981), Bakker (1983), $\checkmark$ an der Zwan (1983). Eyzenga (1984), Duthues (1985), Feenstra en Van de Poel (1985) en Muysken en Schreuder (1985). Dat hier geen sprake is van en louter binnenlandse agagelegenheid mag blijken uit recente Duitse publicaties als van Kappler (1983) en Schanz (1984). In de Engelsuatige literturur worde de discussie niet in deze vorm gevoerd. Zoals uht de nam valt het vak al blikk (business administration"), is dhatin altujd al cen bestuurlijke orientatie gevolgd. Dat desalniettemin cen aantal elementen van de Nederlandse discussie ook in de Engel $(1983,1984)$ 
In de discussie staan de rhalve vooral een economisch-theoretische en een praktische orièntatie tegenover elkaar. De andere elementen vormen daarvan min of meer de afgeleiden. In het wervolg van dit betoog hoop ik aan te geven dat deze altematieven als minder rivaliserend behoeven te worden opgevat dan zij veelal worden gepresenteerd (zie bijw. Eyzenga, 1984). Daartoe zullen enkele ontwikkelingen in de economische theorie worden besproken die het perspectief bieden van althans een conceptuele integratie van de economische theorie en een praktisch relevante bedrijfseconomie. Het zal namelijk blijken dat een aantal centralc concepten in de nietrestrictieve voorstellen in toenemende mate ook de economische theorie binnendringen. Daardoor wordt de afstand tussen beide, althans vanaf de zijde van de economische theorie, enigermate verminderd. Als gevolg daarvan is het ook beter mogelijk vast te houden aan het economische vertrekpunt voor bedrijfseconomische analyses, zoals gepropageerd door o.a. Bosman en Traas.

Het is waarschijnlijk nuttig daarbij nu reeds aan te geven dat het nat mijn mening vooralsnog een illusie zal zijn te menen dat de spanning tussen de economisch-theoretische en de praktische oriëntatie in de bedrijfseconomie door zulke ontwikkelingen geheel zou kunnen worden weggenomen. De aard van de economische theorie is nu eenmaal overwegend restrictief; de aard van praktijkproblemen op bedrijfsniveau vergt nu eenmaal de beschouwing van veel meer aspecten dan zich in cen restrictief kader laten dwingen. De voornaamste winst van een nauwere conceptuele aansluiting tussen beide is echter dat een meer geintegreerd analysekader wordt verkregen. Voor theoretische analyses wordt duidelijker in welke richting uitbouw van het analysekader gewenst is; hiertoe kan geput worden uit het fonds van praktijkkennis. Voor analyses van praktijkproblemen komt een uitgebreider en specifieker op de problematiek toegesneden analyse-instrumentarium beschikbaar. Het behoeft daarbij nauwelijks meer betoog dat verdergaande mogelijkheden tot integratie ook wenselijk zouden zijn met het oog op terugdringing van het proces van fragmentatie in de bedrijfseconomie.

Een dergelijke strategie, gericht op het zoveel mogelijk laten aansluiten van de theoretische en praktische oriëntatie in de bedrijfseconomie, lijki mij overigens ook de meest realistische. Een empirische wetenschap c.q. een op toepassing gerichte wetenschap, kan zich geen keuze tussen beide orientaties veroorloven (Klant, 1985). Wetenschapssociologisch gezien wordt de bedrijfseconomie ook niet die mogelijklyeid gelaten (Whitley. 1983, 1984). Dit wordt bevestigd door het feit dat de spanning tussen beide oriëntaties al zo lang bestaat als het vak zelf (Locke, 1984; Schreuder, 1985; Muysken en Schreuder, 1985). Dit neemt uiteraard niet weg dat binnen het 
vak plaats is voor specialisaties op (zuiver-) theoretische, empirische en praktische problemen. Voor het vak als geheel is een nauwe conceptuele aansluiting tussen deze specialisaties echter van groot belang, zoals hierboven uiteengezet. In paragraaf 5 wordt getracht aan te tonen dat vanuit economisch-theoretische kant hiertoe recent goede anzetten zijn gegeven. In de navolgende paragraaf wordt eerst cen meer globale inleiding op de verhouding tussen algemene economie en bedrijseconomie gegeven. De teneur daarvan is overigens sterk beinvloed door de daarna te bespreken literatuur.

\section{Algemene economie en bedrijfseconomie}

Het gaat er in deze paragraaf om de verhouding tussen de algemene economie en de bedrijfseconomie te schetsen op een zodanige wijze dat duidelijk gemaakt wordt dat beide beschouwd kunnen worden als onderdelen van de economische wetenschappen. Daarbij wordt niet gepretendeerd dat dit de enig mogelijke uitwerking van de geschetste strategiekeuze is. Dit alternatief wordt slechts geschetst als een mogelike uitwerking, vooralsnog voornamelijk op het conceptuele vlak. In de volgende paragraaf zal dan worden aangegeven hoe deze economisch-conceptuele analyse een mogelijk fundament vormt voor de gewenste (her)integratie van de bedrijfseconomie.

Als uitgangspunt wordt daarvoor genomen het centrale concept waarmee Adam Smith de economische wetenschap grondvestte: de arbeidsverdeling. In iedere economie die het allerprimitiefste stadium achter zich heeft gelaten, vindt een zekere mate van arbeidsverdeling plaats. Het was Smith's stelling dat juist de voortschrijdende arbeidsverdeling de bron van nationale welvaart vormde. Daardoor kunnen immers de vruchten van specialisatie in de arbeid worden geplukt. Toenemende specialisatie leidt echter tegelijkertijd tot een toenemende noodzaak tot coördinatie. Naarmate de specialisatie toeneemt, wordt immers ook de graad van zelfvoorzlening van economische subjecten lager. Zij zullen derhalve door coördinatie met andere subjecten in hun overige behoeften moeten voorzien.

Voor deze coördinatie bestaan nu twee mechanismen die als ideaaltypische tegenpolen kunnen worden aangemerkt. Het eerste mechanisme is 'de markt"; het tweede duid ik aan als 'het plan'. "Bij het eerste mechanisme

"ti Planning wordt hier gebruikt in de betekents van 'bewaste onderlinge afstemming'. Hier. door worden betekenissen van deze term in een pur individuele context uitgestoten. Dit is owerigens slechts een kwestie varn doelmatige terminologia gegeven de doeleinden van dit betoog. Zie voor andere definities wan planning bijw. Bosman (1977, paragraa 8.3) en voor enkele bezwaren vetbonden aan dit specificke gebruk wan de term "planning": Bouma (1982). 
verloopt de coördinatie voornamelijk via de prijsworming. De prijzen leveren voldoende informatie voor de individuele keuzen uit de mogelijke handelingsalternatieven. Bij coördinatie via het marktmechanisme behoeft derhalve idealiter geen bewuste onderlinge afstemming van de handelingen van de betrokken subjecten plaats te vinden. Bij het tweede mechanisme is dit nu juist wel het geval. Er dient collectieve actie te worden ondernonen, mede om individuele doeleinden te bereiken. De hiertoe benodigde informatie kan niet (of in sterk onvoldoende mate) aan prijzen worden ontleend. Onderlinge uitwisseling van informatie en bewuste afstemming van individuele handelingen is nodig. Voor deze bewuste afstemming bestaan overigens uiteenlopende middelen (vgl. Mintzberg, 1979 en Ouchi, 1980). ${ }^{11}$ Ook is van belang op welke wijze de planning tot stand komt, waarbij de gradaties lopen van vrijwillige deelname/consensus tot verplichte deelname/dwang.

Een economisch interessante vraag is nu onder welke omstandigheden gebruik zal worden gemaakt van het ene dan wel het andere coördinatiemechanisme. Het antwoord op deze vraag geeft tevens aanknopingspunten voor de verhouding tussen de algemene economie en de bedrijfseconomie. In onze maatschappijvorm heeft de algemene economie zich immers verhoudingsgewijs sterk gericht op de mark twerking, terwijl de bedrijfseconomie dit mechanisme slechts in de beschouwing heeft betrokken voor zover relevant voor organisaties die met behulp van 'planning and control' worden bestuurd.

Alvorens de relatie tussen algemene- en bedrijfseconomie nader wit te diepen wil ik vier opmerkingen maken die meer licht kunnen werpen op de verschillen tussen 'markt" en 'plan' als coördinatiemechanismen ${ }^{12}$.

1. Er bestaat een zekere spanning tussen, wat Arrow (1974) heeft genoemd, de individuele en de collectieve rationaliteit. Individuele rationaliteit wordt bereikt als een individu als het ware in isolement van zijn omgeving zijn behoeftenbevrediging weet te maximaliseren gegeven zijn schaarse middelen. Collectieve rationaliteit wordt bereikt indien een gemeenschap van individuen zulks bewerkstelligt. ${ }^{13}$

1 Arrow, Ouchi en anderen wigen er bovendian op dat de ondertinge afstemming tussen individuen ook kan platsvinden op basis van groepsnormen, vertrouwen ed. Ouchi spreekt in dat geval wan een "clan"-organisatie. Hier is warschijnlijk sprake van eengrensgeval tussen bewuste en niet-bewuste afstemming.

12. Vervolgens zal worden betoogd dat deze mechanismen in de werkelijkheid meer voorkomen in mengwormen dan in zuivere (idealtypische) worm.

13 Zie werder Arrow (1974, hoofdstuk 1) voor een uitgebreider witenzetting omtrent deze begrippen dan hier mogelijk is. 
Het marktmechamisme nu stelt primair in staat tot het bereiken van individuele rationaliteit. Het stelt ieder economisch subject in staat om in betrekkelijke vrijheid de handelingsalternatieven te kiezen die voor hem- of harzelf rationeel zijn. De vigerende prijzen leveren de daartoe benodigde informatie. Het was Adam Smith's stelling dat een onbelemmerde marktwerking ook zal leiden tot de collectief meest efficiènte uitkomst. Inmiddels is daarop het nodige afgedongen. Een markt kan niet altijd worden gecreëerd (collectieve goederen), nuet alle voorkeuren kunnen er - in dezelfde mate - op tot uitdrukking worden gebracht (door koopkrachtverschillen of door 'geen marktpartij zijn', vgl. toekomstige generaties) en niet alle effecten van beslissingen worden in marktprijzen verdisconteerd (externe effecten). ${ }^{14}$ Voor het bereiken van collectieve rationaliteit is derhalve meer coördinatie nodig dan waartoe het marktmechanisme in staat stelt.

Door collectieve actie kunnen de mogelijkheden tot behoeftenbevrediging voor individuen worden verruimd (Arrow, 1974, p. 16). Hiervoor is een onderlinge afstemming van hun handelingen noodzakelijk. Het mechanisme, waardoor dit tot stand kan worden gebracht, duid ik aan als "planning". ${ }^{\text {s }}$ Planning mikt derhalve op het bereiken wan collectieve rationaliteit. Het plan levert de informatie omtrent de doeleinden waarnatar de subjecten gezamentijk (dus als collectiviteit) zullen streven en op welke wijze zij deze zullen trachten te bereiken, gegeven de hun ter beschikking staande middelen. Of het echter voor ieder van die subjecten individueel-rationeel zal zijn eraan mee te werken, is de vraag. Het antwoord op die vraag hangt onder meer af van de wijze waarop het plan tot stand is gekomen, met welke middelen er uitwoering aan wordt gegeven, en of een gelijk beeld bestaat omtrent de werkelijke of te verwachten externe omstandigheden.

2. Vanuit het gezichtspunt van de algemene economie kan de vraag naar de keuze van het coördinatie-mechanisme zo worden geformuleerd: "Waarom lopen niet alle economische transacties over de markt?'. Het was Coase die in 1937 deze vraag stelde en een anzet gaf tot beantwoording. Zijn antwoord bestond uit het wijzen op de kosten verbonden aan het gebruik van het prijsmechanisme als informatiesysteem. In de eerste plaats dienen de relevante prijzen te worden opgespoord. Voorts zijn er kosten verbonden aan de opstelling van contracten voor marktransac-

14 Verder geldi Smith"s stelling alleen bij volkomen concurrentié, zen situatie die zich in de werkelijkheid op wele markten niet vootodoer. En voorts moet crop worder gewezen dat van de uitkonsten van volkomen concurtentie slechts knn worden gezegd dat zij eniciènt zijn, niet dat zij rechwatdig zijn (zie ook Schreuder, 1981, paragraaf 2.3).

15. $\mathrm{Vgl}$. nool 10 . 
ties. En tenslotte kunnen er omstandigheden zijn waronder volledige contractspecificatie onmogelijk of economisch ongewenst is. Een bedrijf wordt derhalve door Coase gezien als een institutie die de kosten verbonden aan het prijssysteem ontloopt en die in stat stelt tot contracten die niet gemakkelijk over de markt tot stand komen. Het is juist de aanzet van Coase die na vele jaren een vervolg heeft gekregen in het moderne onderzoek. Hierop wordt in de volgende paragraal teruggekomen.

3. Vanuit het gezichtspunt van de bedrijfseconomie zou de vraag kunnen luiden: 'Waarom lopen niet alle economische transacties over eén bedrijf c.q. over bedrijven?" Eén antwoord hierop ligt voor de hand: omdat er ook kosten verbonden zijn aan het gebruik van planning als coördinatiemechanisme. Dit zijn de kosten van de opstelling, de communicatie en de implementatie van de plannen. Tevens zullen er omstandigheden zijn waaronder de planning faalt aangezien de benodigde onderlinge afstemming op geen enkele wijze kan worden bereikt. Vergelijking van de antwoorden op de vragen onder punten 2 en 3 verwijst naar de noodzaak van een comparatieve analyse van transactiekosten onder verschillende coördinatiemechanismen.

4. Er moet verder op worden gewezen dat de keuze tussen de verschillende coördinatiemechanismen niet geheel door economische factoren wordt bepaald. Die keuze vindt plaats binnen maatschappelijke constellaties met uiteenlopende waarden-oriëntaties en machtsverhoudingen. Daaruit vloeien wenselijkheden c.q. randvoorwaarden woort die de keuze in belangrijke mate mede bepalen. Zo wordt op nationaal niveau de afweging tussen deze mechanismen (sterk) medebepaald door politieke factoren. En zo is het eveneens waarschijnlijk dat sociaal-culturele factoren de keuze tussen coördinatiemechanismen binnen een bepaalde maatschappij mede bepalen. Organisatiewormen lijken niet onathankelijk van cultuurvormen (vgl. Lammers en Hickson, 1979 en Hofstede, 1983).

In het voorgande is de nadruk gelegd op de verschillen tussen de coördinatiemechanismen 'markt' en 'plan'. Hierdoor moet niet de indruk ontstatan dat er sprake is van een duidelijke scheidslijn tussen de werkingssferen van beide mechanismen. Het tegendee is eerder waat: mengvormen van deze mechanismen likken meer voor te komen dan hun zuivere vormen. De gemengde economie als tussenvorm van een markt-en een planeconomie is

16 Alsmede eventued de kosten van niet-realisatie van de plannen voor zover namelik door planning een lagere bruto-opbrengs zou worden verkregen dan bij onbelemmerde werking van het markmechanisme her geval zon ajin geweest. 
wellicht én voorbeeld. Bij vele marktransacties zal ook een zekere afstemming tussen de marktpartijen voorkomen (denk aan de wele contacten tussen grote afnemers en hun vaste leveranciers). En tot slot kunnen ook binnen bedrijven marktwormen worden onderscheiden. (Bijv. de interne arbeidsmarkt, de gediversifjeerde onderneming als vermogensmarkt, internal competition c.q. "intrapreneurship').

Samenvattend kan worden gesteld dat alleen een comparatieve analyse van de transactiekosten onder verschillende coördinatiemechanismen uitsluitsel kan geven over de vraag van welke coördinatiemechanismen in welke onstandigheden gebruik moet worden gemaakt ter voorbereiding en uitvoering van economische transacties. In onze maatschappijvorm heeft de algemene economie zich primair gespecialiseerd op de markt als coördinatiemechanisme; de bedrijfseconomie op planning binnen (en tussen) organisaties. Zoals gezegd, is de situatie, waarin een mengvorm van beide mechanismen kan worden aangetroffen, waarschijnlijk de meest voorkomende. Bijgevolg kunnen de algemene economie en de bedrijfseconomie als complementair worden opgevat waarbij zij elkaar belangrijke inzichten kunnen bieden omtrent bepalde vormen van het woorbereiden en uitvoeren van economische transacties. ${ }^{17}$

Accepteert men een dergelijke omschrijving van het economisch arbeidsveld - de bestudering van de voorbereiding en uitvoering van economische transacties; door Williamson (1975) aangeduid als het 'transactional paradigm' - dan wordt daarmee een antwoord verkregen op de vraag naar de verhouding tussen de algemene en de bedrijfseconomie. Het transactieparadigma laat zich overigens naar mijn mening zeer wel verenigen met het traditionele keuzetheoretisch paradigma (zie Muysken, 1985) van de economische wetenschap, maar voegt daaraan een aantal elementen toe. Dat zijn merendeels elementen die van belang zijn in de processen van voorbereiding en uitvoering van economische transacties. Zoals hieronder verder zal worden betoogd, zijn het juist deze elementen waarvoor in de bedrijtseconomie bijzondere aandacht bestaat.

In de bovenstaande stelling dat de algemene economie en de bedrijfseconomie als complementair kunnen worden opgevat, herkent men de zienswijze die in de inleiding als "economieèn bedrijven" is aangeduid. De bedrijfseconomie makt in deze visie deel tit van de economische wetenschappen omdat zij zich richt op de voorbereiding en uitvoering van econo-

17 Zo makt de bedrifscconomie veetal gebruik van algemeen-economische instrumenten, zodra zij de markt werking bestudeert. Joan Muysken (1985) matkt in ziju oratie aranemelijk dat de bedrijfsconomic drarentegen de algemene economic inzichten kan aanrek en omtrent het gedrag van economische subjecten onder omstandigheden wan onderlinge beimwloeding. onzekerheid on onvolledige informatie. 
mische transacties. In die zin is bedrijfseconomie bepaald economie. Echter, met haar belangstelling voor het bedrijf als de institutie waarbinnen zulke transacties worden voorbereid en ten dele ook plaatsvinden, heeft de bedrijfseconomie zich in het bijzonder gericht op het coördinatienechanisme van de planning. Dat wil zeggen: op die situaties waarin het prijsmechanisme ontbreekt of onvoldoende informatie oplevert, zodat (ook) op andere wijze de afstemming tussen subjecten moet plaatsvinden. Zulke situaties stellen geheel eigen problemen, die sterk afwijken van de problemen bij de uitvoering van iransacties over de markt op basis van louter het prijssignaal. Twee belangrijke categorieën van zulke eigen problemen zijn:

a) Hoe dient de informatie die niet of onvoldoende door het prijsmechanisme wordt geleverd te worden verzameld, bewerkt, ten grondslag gelegd aan de planning, gecommuniceerd door de organisatie, en te worden gebruikt bij de evaluatie en bewaking van de planning?

b) Welke gedragsmatige effecten treden op in situaties waarin subjecten niet louter prijs- of hoeveelheidsaanpassers zijn, maar enige verdere speelruimte hebben in hun gedrag?

Deze en andere problemen geven een zodanig eigen tichting en inhoud aan de bedrijfseconomie dat hier gesproken kan worden van een tamelijk verzelfstandigd vakgebied, dat weliswaar overlappingen en raakvlakken kent met de algemene economie, maar overigens eigen-aardig is.

\section{Een economisch integratiekader voor de bedrijfseconomie}

In het voorgaande is er steeds van uitgegaan dat er behoefte bestat aan een integratiekader voor de deeldisciplines wan de bedrifseconomie. Ik heb betoogd dat in de verhouding tot de algemene economie het fundament voor een dergelijk integratiekader kan worden gevonden. De bedrijfseconomie richt zich in deze visie in het bijzonder op organisaties die economische transacties voorbereiden en uitvoeren en wel onder omstandigheden waarin de coördinatie niet (geheel) op basis van het prijsmechanisme kan plaatsvinden. In deze paragraaf zal dit integratiekader nader worden uitge werkt. Dat zal gebeuren door aandacht te schenken atu ontwikkelingen in de economische theorie die zich nu juist op zulke situaties hebben gericht. Daarmee wordt geillustreerd dat er sprake is van enige toenadering van de algemene en bedrijfseconomie op dit terrein. Tevens wordt hopelijk duidelijk gemakkt dat deze ontwikkelingen een perspectief bieden op een geïntegreerde conceptuele analyse van de voorbereiding en uitvoering van economische transacties. Dit perspectief maakt het aantrekkelijker vast te houden aan een economisch "vertrekpunt" voor de bedriffseconomie, zoals bepleit door Bosman en Traas. 
De bedoelde ontwikkelingen in de economische theorie hebben betrekking op de "theory of the firm". In tegenstelling tot wat de naam doet vermoeden, kan de standaard-uitwerking van deze theorie beter worden gekenscherst als een theorie van markten. Het bedrif is in deze theorie een 'zwarte doos' waarop een gedragshypothese is geplakt. Deze 'zwarte doos' ontvangt zijn informatie uit markten en reageert daar onmiddellijk op conform de gedragshypothese. Hoe het interne functioneren van de doos verloopt, blijf onbeantwoord in de "theory of the firm". Wellicht waren economisten wel beschroomd deze doos te openen uit de gerechtvaardigde vrees dat Pandora er de eigenares van zou blijken te zijn (zie ook Muysken, 1985).

Zoals vermeld, vormde Coase (1937) een vroege uitzondering op deze regel. Hij kenschetste het bedrijf als een institutie warin het prijsmechanisme is vervangen door het gezag van de ondememer:

"Outside the firm, price movements direct production, which is co-ordinated through a series of exchange transactions on the market. Within a firm, these market ransactions are eliminated and in place of the complicated market structure with exchange transactions is substinuted the entrepreneur-co-ordinator who directs production" (Coase, 1937, p. 333).

De bestaansreden van het bedrijf is in de visie van Coase gelegen in zijn comparatief voordeel bij het uitvoeren van bepaalde economische transacties. Deze atanet wan Coase is op twee wijzen verder uitgewerkt, namelijk (1) door middel van een comparatief-statische analyse, die hieronder eerst zal worden besproken, en (2) door middel van een comparatief-institutionele analyse, die zowel statische als dynamische elementen bevat. De laattstgenoemde analyse komt vervolgens aan de orde.

Door Alchian en Demsetz (1972) is de comparatief-statische variant ontwikkeld. Zij vroegen zich met name af waarop het gezag van de ondernemer/manager dan wel berust. In hun analyse vloeit dit gezag yoort uit de omstandigheden waronder het efficient zal zijn de produktie bimnen een bedriff te organiseren. Dat zal immers in het algemeen het geval zijn indien het mogelijk is de produktiviteit te verhogen door team-produktie. Teamproduktie is daarbi gedefinieerd als produktie warin (1) gebruik wordt gemaakt van diverse soorten inputs en waarbij (2) de produktie meer bedraagt dan de optelsom van de outputs van de afzonderlijke inpurfactoren. In een dergelijke situatie van team-produktie zijn de individuele

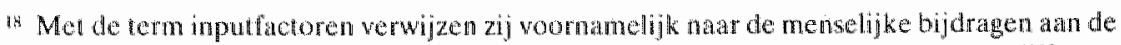
teameproduknis: "Our problem is viewed basically as one of organization among different people, not of the physical goods or services, however much there must be selection and choice of combination of the latter" Alchian en Demsetz, 1972. p. 779). 
bijdragen van de inputfactoren aan de team-produktie (de marginale produktiviteiten) moeilijk vast te stellen. De aandacht verschufft daardoor naar hun input-bijdragen.

In een enigszins complexe situatie zullen deze inputs echter moeilijk precies waarneembaar zijn of in ieder geval niet kosteloos vastgesteld kunnen worden. Aangezien de beloning van de produktiefactoren niet kan plaatsvinden op basis van hun marginale produktiviteit kan het onder deze omstandigheden individueel-rationeel zijn minder inspanningen te verrichten dan uit het oogpunt van het team wenselijk zou zijn. Onder deze omstandigheden zal het volgens Alchian en Demsetz lonend kunnen zijn een 'monitor' aan te stellen. Deze monitor wordt betaald uit de meeropbrengsten van team-produktie boven individuele produktie. De monitor heeft tot taak over de produktiebijdragen van de inputfactoren te waken en daarvoor als het ware steeds 'contracten' af te sluiten. Als onderdeel van zijn taak verkrijgt de monitor daarmee de macht de contractvoorwarden met individuele inputfactoren te wijzigen c.q. de contracten te beèindigen. Het gezag van de ondernemer/manager wordt daarmee dus verklaard als onderdeel van een contractrelatie met wederzijds profijt. ${ }^{19}$

In de analyse van Alchian en Demsetz (1972) speelt informatie derhalve een centrale rol. Doordat de individuele bijdragen aan de team-output niet zijn wast te stellen, dient informatie te worden verzameld omtrent de inputbijdragen. Ook dit kan meestal niet rechtstreeks c.q. kosteloos gebeuren. De ondernemer/manager nu specialiseert zich in deze informatieverzameling en het nemen van beslissingen (namelijk contract-wijzigingen) op basis daarvan:

"The employer, by virue of monitoring many inputs, acquires special superior information about their productive talants. This aids his direcrive (i.e., market hiring) efficiency. Ho "sells" his information to employe-inputs as he aids thern in ascertaining good input combinations for team activity... Efficient production with hoterogeneous resources is a result nof of having better resources but in knowing more accurately the relative productive performances of those resources' (Alchian en Demsetz, 1972, p. 793).

\footnotetext{
17. Alternatieve hypothesen zin (a) dat diegene tot 'monitor' wordt angewezen wicns bij. drage nog het moeilikst rreetbar is, zodat ar cen "incentive for self-monitoring" word geschapen en (b) dat de drager van het grootste bedriflspecifieke rsica de monitoring-funetie zal willen verkrijgen (vgl. Barzel, 1983 an Alchian, 1983). Het gatl mij hior nicl om de juistheid van deze hypothesen, mas on de andach in de economische theoric wour dit vrágsuk.
} 
Al met al typeren Alchian en Demsetz bedrijven als een '... specialized market institution for collecting, collating and selling input information" ( $\mathrm{p}$. 793). ${ }^{23}$

Het contractuele gezichtspunt is door onder meer Ross (1973), Jensen en Meckling (1976), Fama (1980) en Fama en Jensen (1983a, 1983b) verder uitgewerkt. Daarmee is de basis gelegd voor de 'agency'-literatuur. Daarin wordt het bedrijf gezien als een knooppunt van 'contracten' c.q. wederzijdse afspraken. ${ }^{21}$

De centrale vraggstelling van de agency-literatur is welke vorm deze contracten onder specifieke omstandigheden zullen aranemen. Tot die omstandigheden behoren onder meer de externe ontwikkelingen, de risicohouding (c.q. nutsfuncties) van de betrokkenen ${ }^{22}$ en de beschikbare informatic. De analyse richt zich met name op de veronderstelde gedragseffecten bij onderscheiden contractvormen. Daarbij gaat het dan weer vooral om de invloed op de produktieve prestaties van verschillende contractspecificaties (het 'shirking'-vraagstuk).

In de agency-analyse is het de taak van het management om te komen tot een zodanig stelsel van 'contracten' (wederzijdse afspraken) dat de overleving van de organisatie het beste gediend wordt (vgl. Fama en Jensen, 1983b). Het maken van die afspraken kan worden vervat in het begrip planning, zoals dat in het voorgaande is gedefinicerd als bewuste onderlinge afstemming. Het bewaken van die afspraken behoort eveneens tot de tak van het management. In de agency-literatuur worden daarvoor de 'monitoring'- en 'bonding'- mechanismen genoemd. Een bredere aanduiding van deze problematiek wordt mijns inziens verkregen met de gebruikelijker term 'control'. Aldus blijkt dat de agency-literatuur beschouwd kan worden als een verrijking van de economische theorie, waarin speciale aandacht wordt gegeven aan het bestuurlijke vraagstuk in termen van planning en control. Daarbij spelen de informatie- en gedragsaspecten een belangrijke rol. Het zal de lezer opvallen dat deze interpretatie nauw

20 Vinut bedrifrseconomisch gezichtspunt is het de vaag of deze analyse niet moet worden uigebred tol athdere typen informatis. Het zou immers heel goed kumnen zijn dat juist de tearm-produktie wan gocde informatie (tet anzien van inteme en exieme omstandigheden) ecnonderscheidend kenmerk van organisaties is. Tevens verwaarlozen Alchian en Demsetz in hum analyse te zeer de mathagementtak wan werkotganisatic. Deze taak omvat amzienlijk meer dan individuele contract (her)onderhandelingen. Zie voor enige verdere bezwaren Moerland (1982).

21 De term "contracten" dient namelijk niet uitshitend in juridische zin te worden geinterpreteerd. In de agency-literatum wordt ook veelvuldig gesproken van "implicit" of "unwritten contracts" een concept dat uit een oogpunt van operationaliteit bezwaren oproept. (vgl. Schreuder, $1983, \mathrm{p} .45)$.

22 Zie hierover Moerland (1982). 
aansluit bij de heroriënteringsvoorstellen voor de bedrijfseconomie die in het voorgaande de revue zijn gepasseerd.

Intussen moet de betekenis van deze ontwikkeling niet worden overschat. Er moet bijv. nog met bijzonder restrictieve veronderstellingen worden gewerkt om de agency-modellen hanteerbaar te houden. Deze veronderstellingen zijn ook niet alle even plausibel (vgl. Kaplan, 1984). Desalniettemin is reeds aansluiting verkregen met onderdelen van vooral de financierings- en de berichtgevingstheorie in de bedrijfseconomie (zie Jensen en Smith, 1984 en Watts en Zimmerman, 1985) en mag worden verwacht dat deze ontwikkeling voort zal gaan.

Door Williamson (1975) is vooral de comparatief-institurionele analyse, waartoe Coase eveneens de aanzet had gegeven, verder uitgewerkt. Hij heeft zich met name afgevraagd wat nu precies de factoren zijn die de uitwoering van transacties over de markt bemoeilijken of zells onmogelijk maken. Deze factoren worden door hem gegroepeerd in (a) de karakteristieken van menselijke besluitvorming en gedrag en (b) omgevingskarakteristieken. Tot de eerste categorie behoren de beperkte rationaliteit die mensen kunnen bereiken ("bounded rationality") en het strategisch gedrag dat zij ten toon kunnen spreiden ("opportunism"). Hun beperkte rationaliteit vormt een probleem indien zij moeten opereren in een complexe. onzekere omgeving. Het kan dan te kostbaar of zelfs onmogelijk zijn de gevolgen van alle handelingsalternatieven te overzien en op basis daarvan een contract te specificeren dat de basis van een markttransactie kan zijn. Bijgevolg kan het voordeliger zijn een organisationele rellatie aan te gaan en de specificatie van het contract geleidelijk te doen plaatsvinden naarmate de onzekerheid in de loop der tijd wordt gereduceerd. Opportunistisch of strategisch gedrag vormt met name een probleem indien partijen op elkaar aangewezen zijn voor de uitvoering van een transactie. Deze conditie wordt door Williamson aangeduid als 'small numbers exchange'. In een dergelijke situatie is het immers moeilijk of onmogelijk de wederpartij voor opportunistisch gedrag af te straffen door verbreking of niet-verlenging van het contract.

Door Williamson (1975) zijn deze vier factoren (beperkte rationaliteit opportunisme, onzekerheid en 'small numbers exchange') gecombineerd in het zgn. "organizational failures framework" of "markets and hierarchies'paradigma. Met behulp van dit analysekader onderzoekt men of in specifieke omstandigheden de markt dan wel de organisatie ("hietarchy") het meest geschikte coördinatiemechanisme vormt. Daarbij richt de analyse zich op de transactiekosten, die onder de alternatieve coördinatiemechanismen zullen ontstaan als gevolg van de interactie van de vier genoemde factoren. Weer is een centrale rol toebedeeld aan het informatic-aspect. 
Dit wordt door Williamson geintroduceerd als voormamelijk een affeleide van de factoren onzekerheid en strategisch gedrag. Indien een van de partijen betrokken bij een transactie een informatievoorsprong heeft en de andere partil slechts tegen hoge kosten deze voorsprong teniet kan doen ${ }^{23}$, ontstat in Williamson's terminologic een situatie van 'information impactedness", waardoor de potentiele kosten van transacties zullen oplopen. Met behulp van institutionele mechanismen zall dan een oplossing voor deze informatie-asymmetrie en de daaraan verbonden hoge transactiekosten moeten worden gezocht. Het hier beknopt aangeduide analysekader is onder meer toegepast op aspecten van de arbeidsrelatie (Williamson e.a., 1975; Pfeffer en Cohen, 1984), biedingen voor franchise-contracten (Williamson, 1976), verticale integratie (Williamson, 1975), oligopolie (Willamson, 1975), aspecten van inflatie (Wachter en Williamson, 1978) en het ontwerp van organisaties (Ouchi, 1979, 1980; Williamson en Ouchi, 1981; Williamson, 1981; Maitland e.a., 1985).

Vooral bij de verklaring van de arbeidsrelatie, verticale integratie en organisatie-ontwerp komen interessante verbindingen met de bedrijfseconomische theorie tot stand. Deze verbindingen worden vergemakkelijkt doordat gebruik wordt gemakt van een aantal concepten dat al langer in de bedrijfseconomie wordt gehanteerd (beperkte rationaliteit, strategisch gedrag, onzekerheid). Daardoor wordt aansluiting verkregen tussen de micro-economische 'theory of the firm' en de bedrijfseconomische organisatietheorie, twee leerstukken die, zoals eerder vermeld, in het verleden een vrijwel geheel gescheiden bestaan leidden. ${ }^{24}$

De bedoeling van deze paragraaf was on duidelijk te maken dat er sprake is van enige toenadering tussen de algemene economie en de bedrijfseconomie waar het betreft de analyse van situaties waarin voor de coördinatie van transacties niet (geheel) op de werking van het prijsmechanisme kan wordlen vertrouwd. De hierboven beknopt aangeduide literatuur maakt dit ons inziens aannemelijk. ${ }^{25}$ Daarbij is de 'opbrengst' van deze

23 Er mag immers vanwege de mogelijkheid wan strategisch gedrag niet vertrouwd worden op "aerlijk delen" van alle informatio (Williamson, 1975. p. 14 en hoofdstuk 2).

as Opgenterkt kan nog worden dat de comparatiefubsitutionele bendering in principe breder is dan de comparatief-stutische (zife Schreuder, 1983). Er kunnen echter ook een aratal bezwren regen worden ingebrach (rgl. Schreuder, 1983; Francis e.a. 1984; Matlande.a., 1985) die chter merendeds het thema van deze paragrat - de conceptuete toenadering tussen micromeconomische theorie en de bedrijtseconomie - niet raken.

s Ook op andere terremen zien wij een zekere toenadering tussen de algemene economie en bedrifficconomie. Daarloe behoren onder meer het werk van Ponter (1980, 1985) waarin verbindingen worden gelegd tussen de ongatisatiestrategie en industriele economie; en de integratie wh micro connomic en bedrijlseconomische theoreën zads onder meer blikend uit het owerzichtswark van Kousoyisnnis (1982) terzake van 'fuiet-prijs"-beshissingen. 
ontwikkeling vooralsnog voornamelijk gelegen op het conceptuele vlak. De economische theorie heeft haar aandacht verbreed tot de interne werking van het bedrijf. Zij reikt concepten aan warmee algemeen-economen en bedrijfseconomen op soortgelijke wijze "tegen bedrijven aan kunnen kijken". Van een aantal van deze concepten wordt (of werd) in sommige bedrijfseconomische deeldisciplines al gebruik gemaakt. Daarmee komen niewwe verbindingen met de economische theorie tot stand. Aangezien die verbindingen zich reeds witstrekken tot meerdere bedrijfseconomische deeldisciplines, doemt het perspectief op van niet alleen een meer integrale beschouwingswijze van de algemene en de bedrijfseconomie, maar ook van een gemeenschappelijk economisch 'vertrekpunt' van de bedrijfseconomische deeldisciplines. Vanuit deze optiek luidt dan immers steeds de basisvraag van welke coördinatiemechanismen in welke omstandigheden gebruik moet worden gemaakt ter voorbereiding en uitvoering van economische transacties. Of in de taal van de niet-restrictieve bedrijfseconomie: welke vormgeving moet worden gekozen voor de organisatorische en marktrelaties van een bedrijf om een optimaal antwoord te krijgen op het "bestuurlijke vraagstuk'?

Tegelijkertijd moet worden opgemerkt dat deze verbindingen het gemakkelijkst worden gelegd met die delen van de bedrijfseconomie die onder restrictieve strategieën zijn of worden ontwikkeld. De reden is duidelijk: ook in de algemene economie word overwegend zo'n strategie gevolgd. De aangeduide ontwikkelingen vormen weliswaar pogingen om de beperkende vooronderstellingen van de analyse gaandeweg te versoepelen, maar in vergelijking met de complexe werkelijkheid waar de nietrestrictieve strategie zich op richt, valt er dan nog een zeer lange weg te gaan. ${ }^{26}$

\section{Samenvatting en slotbeschouwing}

Het uitgangspunt van deze rede werd gevormd door het bestaan van tenminste drie visies op de bedrijfseconomie. Deze bleken voomamelijk te verschillen in het gewicht dat wordt gegeven aan enerzijds de theoretische orièntatie van het vak (met name de grondslag in de economische theoric) en anderzijds de praktische oriëntatie. Tussen beide oriëntaties bestaat van oudsher een bepaalde spanning. Tevens werd opgemerkt dat tussen de resultaten van beide benaderingen in het algemeen onvoldoende aansluiting bestaat. Deze constateringen hebben geleid tot een levendige discussie

2* Voor wat betreft de agency-literatur kan er echter op worden gewezen dat deze zowel op restrictieve (analytical theory of agency) als niet-restrictieve wije (postive theory of agency) wordt uitgebouwd (vgl. Schreuder, 1983). 
in de bedrijfseconomic omtrent mogelijke herorienteringen van het wak.

In deze rede heb ik gepoogd te illustreren dat de in deze discussie naar voren gebrachte alternatieven als minder rivaliserend behoeven te worden opgevat dan zij veelal worden gepresenteerd. Zij die pleiten voor een meer praktisch georienteerde bedrijfseconomie, beklemtonen vaak de noodzaak wan meer aandacht voor: het 'bestuurlijke vraagstuk', planning and control, beperkte rationaliteit, onvolledige informatie en de gedragsmatige aspecten van handelingsalternatieven. Zij wensen een meer integrale en operationele bedrijfseconomische analyse ontwikkeld te zien, waarbij overigens veelal vastgehouden wordi aan een economisch vertrekpunt voor deze analyse. Ik heb getracht met twee voorbeelden te laten zien dat de (micro-)economische theorie zich ontwikkelt in een richting, die het perspectief biedt op een meer integrale analyse. Concepten als beperkte rationaliteit, onvolledige en asymmetrische informatie, belangentegenstel. lingen bimnen een organisatie, en de gedragseffecten van alternatieve vormgevingen van de relaties binnen een organisatie, dringen in toenemende mate de economische theorie binnen. Daarbij wordt de taak van het management opgevat als het ontwerp en de bewaking van een zodanige verzameling afspraken tussen de deelgenoten in een organisatie dat de levensvatbaarheid ervan zo goed mogelijk wordt gediend. Deze opvatting vertoont een goede correspondentie met wat hiervoor werd aangeduid als 'het bestuurlijke vraagstuk'.

Steeds is beklemtoond dat de vruchten van deze ontwikkeling nog voornamelijk moeten worden gezocht op het conceptuele vlak. De afstand tussen de "taal" van de economische theorie en de (praktijkgerichte) bedrijfseconomische visie wordt erdoor verkleind. Daardoor wordt het beter mogelijk vast te houden aan een economisch vertrekpunt van de bedrijfseconomische analyse. Tevens wordt een mogelijkheid geboden voor conceptuele integratie van de bedrijfseconomische deeldisciplines, ook in verhouding tot de algemene economie. Steeds luidt dan immers de centrale vraagstelling op welke wijze de meest efficiënte vorm van voorbereiding en uitvoering van economische transacties kan worden bereikt.

Kont door deze ontwikkeling ook een meer operationele bedrijfseconomie in het verschiet? Dat wil zeggen een bedrijfseconomie die concretere aanwijzingen oplevert voor handelingsaltermatieven in de praktijk? Dat valt nog te bezien; daarvoor zijn de hier besproken aanzetten nog te recent. Wel kan hierover ter afsluiting nog een tweetal opmerkingen worden gemakt. Ten eerste dat de bedrijfseconomie in het verleden juist op basis van goede economische theorievorming een aantal malen zulke aanwijzin- 
gen heeft kunnen genereren. ${ }^{27}$ En ten tweede dat woor een goede aansluiting tussen theorie en praktijk ook gewerkt moet worden aan de generalisatie van inductief verkregen kennis tot bedrijfseconomische theorie. Wellicht ligt hier wel de voornaamste taak voor bedrijfseconomen in de komende jaren. ${ }^{28}$ Hoe dit ook zij, het is mijn overtuiging dat de bedrijtseconomie zich geen keuze tussen haar theoretische en praktische orientatie kan veroorloven. Wij zullen moeten leren leven met een zekere mate van spanning in ons vak en moeten blijven streven naar zowel een stevige theoretische fundering ervan als naar praktische relevantie. ${ }^{20}$ Het is een voorrecht en een uitdaging aan onze nieuwe faculteit op deze wijze economieèn te mogen bedrijuen.

\section{Literatuur}

Alchian, A.A., Reminiscences of errors: a tribute in homor of Dean Willam $H$. Meckling on his retirement, Working Paper MERC 83-16, University of Rochester, 1983.

Alchian, A.A. en H. Demsetz, Production, Information Costs, and Economic Organizanon, American Economic Review, december 1972, pp. 777-795.

Arrow, K.J., The Limits of Organization, Norton, New York "1974.

Bakker, J.J.A., Bestuurtijke bedrifseconomie? De Accowntam, jaargang 89, 11\%. 9. 1983.

Barzel, Y., The Residual Claim as the Entreprenetury Reward for Self-Policng. Discussion Paper Nr. 83-3, University of Washington, 1983.

Bindenga, A.J., De bedriffecomomische basis van de accountancy (intreerede Uniwersiteit tan Amsterdam, 1981), Samsom. Aphen aan den Rijn 1981

Blaug, M., The Methodology of Economics, Cambridge University Press, Cambridge (UK). 1980.

Bosman, A., Een metatheorie over het gedrag van organisates, Stenfert Kroese, Leiden, 1977.

Bosman, A., Bedrijfseconomie, warom anders?, Maandblad woor Accounancy en Bedrijfshuishoudkunde, November 1980, herdrukt in: 1973 MAB 1983, Muusses, Purmerend, 1984.

Bouma, J.L., Inleiding tor de bedrijfeconomie, Delwel, Wassenaar 1982.

Coase, R.H., The Nature of the Firm, Economica, Vol. 4, 1937, pp. 386-405, herdrukt an: G.J. Stigler en K.E. Boulding (red.), Readings in Price Theory, lrwin. Homewood (IIl.), 1952 .

Durfhues, P.J.W., Naur ten therorientatie" van de bedrifseconomie of nataren herniouwd contact tussen de theoriz en de praktijk?, $\mathrm{Dk}_{3}$ Accoumtant Januari $1985, \mathrm{pp}, 285-288$.

27 Lie noot 6 . Een andere taak van de bedrijfseconomic betreft, zoals ecrder betoogd, de systematisering en generalisatie van inzichten opgedaan uit bestudering van de praktik. Hicrover gat ook de latste opmerking.

2 Zie hierover onder meer de recente publicaties van Kaplan (1983, 1984).

$2 \%$ Zie Schreuder (1985) woor een beschouwing ower de spanning tussen die theoretische en praktische oriênatie in de berichtgevingstheorie en een poging tot de anduiding van enkele factoren die deze spanning kunnen verklaren. 
Eyzenga, G.R., De positicbepaling van de modeme bedrij fseconomie als thitgangspunt voor de keuze van een toekongtige koers; ean slech gestructureerd probleem? De Accom: tant,januari $1984, p p .324-330$.

Fama, E.F., Agency Problems and the Theory of the Finm, Joumal of Political Economy, Vol. 88, nr. 2, 1980, pp. 288-307.

Fama, E.F. en M.C. Jensen, Separation of Ownership and Control, Joumal of Law and Economies, juni $1983 \mathrm{a}$, pp. 301-326.

Frma, E.F, en MC. Jengen, Ageney Problems and Regidual Clans, Joumal of Law and Economics, juni $19836, p p .327-350$.

Feenstra, D. W, en J.H.R. van de Poel, Bedrijfseconomie, methodologie en besluitworming (1, II en III), Maandblad noor Accoumancy en Bedrijshushoudkunde, januari, februari, matat 1985, pp. 22-30, 65-72 en $105-115$.

Francis, A., J. Turk en P. Willman (red.), Power, Efficiengy and Hatitahons, Heinemann, Londen, 1983.

Hofsuda, G.H., The Cultural Relativily of Organizational Practices and Theories, Journat of International Business Sindies, 1983, pp. 75-89

Helden, G.J. wan, J.H.R. wan de Poel en F.M. Tempelaar, Een andere bedrijfseconomie? Matandblad voor Accoumancy en Bedriffshushoudkmo. November 1980, herdrukt in: 1973 MA B 1983, Muusses, Purmerend, 1984.

Jensen, M.C, en W.H. Meckling, Theory of the Firm: Managerial Behavior, Ageney Costs and Ownership Structure, Journal of Financial Economics, oktober 1976, pp. 305-360.

Jensen, M.C. en C.W. Smith jr., The Modern Theory of Corporate Finance, McGraw-Hill, New York, 1984.

Kaplan, R.S., Comments on Wilson and Jensen, Accouming Review, april 1983, pp. 340-346.

Kaplan, R.S., The Evolution of Management Accounting, Accounting Review, juli 1984, pp. 390.418.

Kappler, E. (red.), Rekonstruktion der Betriebswirtschaftslehre als okonomische Theorie, Verlag René F. Willer, Spardorf, 1983.

Klant, J.J., Kunstleer tegen wil en dank, in: J. Muysken en H. Schreuder(red.), Economische Wetenschappen: eenheid in versicheidemheid?, Van Gorcum, Assen, 1985.

Koutsoyiannis, A. Non-Price Decisions. The Firm in a Modern Conext, Macmillan, Londen, 1982.

Lammers C.J. en D.J. Hickson, Organizations, alike and unalike, Routledge and Kegan Paul, Londern, 1979.

Locke, R.R., The infuence of past systems of management educarion on current systems: the German case, Brussel, Working paper 1983-14, European Institute lor Advanced Studies in Management, 1983 .

Maitland, I., J. Bryson en A van de Ven. Sociologists, Economists, and Opporturism. Acadeswy of Managentent Review, Vol. 10, ar. 1, 1985, pp, $59-65$.

Mintzberg. H., The Sinchuring of Organizations, Prentice-Hall, Englewood Clifs, 1979.

Moenland, P.W. Zeggenschap, risico en de verdeling der toegevoegde waarde, cintreerede Rijksuniversiteit Groningen), Stenfert Kroese, Leiden, 1982.

Muysken, J., Hoe algemeen is de algemene economie? (intreerede Rijksunversiteit Litn. burg) in: J. Muysken en H. Schreuder (red.), Economische wetenschappen eenheid irn verscheidewheid?, Van Gorcum, Assen, 1985.

Ooninck, J.A.M., Bestumilke Informatekande, (intreerede Katholieke Hogeschool Til. burg), Samsom, Alphen aan den Rijn, 1983.

Ouchi. W.Gi., A Conceptual Framework for the Design of Organizational Control Mechanisms, Management Science. Vol. 25, 1979, pp. 833-848.

Ouchi, W.G., Markets, Buraucracies, and Clans, Adminisrotive Science Quarterly, maart 1980 . pp. 129.141 . 
Pantin, C.F.A., The Relaron between the Sctences, Cambridge Universty Press, Cambridge (UK), 1968.

Pfeffer, J. en Y. Cohen, Determinants of Internal Labor Markets in Organizations, Admatstrative Science Quarterly, Vol. 29, nr. 4, 1984, pp. $550-572$.

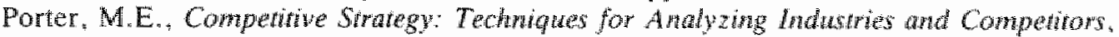
The Free Press, New York, 1980.

Porter. M.E., Competitue Adrantage: Creatug and Sustainig Superior Perfomance. The Free Press, Mew York, 1985.

Ross, S.A., The Economic Theory of Agency: The Principal's Problem. American Economic Review, mei 1973, pp. 134-139.

Rossum, W. van, De economie als niet-restrictieve discipline?, in: J. Muysken en $\mathrm{H}$. Schreuder (red.), Economische weterschappen: evheid in verschetdewheid? Van Gorcum, Assen, 1985.

Schanz, G (red.), Betriebswirbchafislehre wnd Nationalokonomie, Gabier, Wiesbaden, 1984.

Schreuder. H., Maatschappelige veranwoovdeligheid en madschappelijke berichgeving wan andermewingen, Stenfert Kroese, Leiden, $198 \%$.

Schreuder, H., Economic Theories of Orgamization: Ar Overwian and Assesment of some Recent Developments, Amsterdam, VU, Research Memorandum $1983-11$, berdrukt: Maastricht, RL. Research Memorandum 85.00\%.

Schreuder, H., Accounting Research and Practice, in: A.H.G. Rinnooy Kan (red.). New Challenges for Managemem Research, Norh-Holland, Amsterdam, 1985.

Simon, H.A., Administrative Behaviar, Macmillan, New York, 1949, 2 ed., 1961.

Simon, H.A., Model's of Man, Wiley, New York. 1957.

Spronk, J., Aftrankelikheid en samenwerking (intreerede Erasmus Universiteit Rotterdam). Kluwer, Deventer, 1984.

Traas, L... Over de noodzaak to herorientering van de (klassieke) bedrijfsecornomic, De Accountant, november 1981, pp. 146-155.

Watts, R. en J.L. Zimmerman, Posinive Theories of Accountmg, Prentice-Hall, Englewood Cliffs, 1985.

Wachter, M. en O.E. Wilhiamson, Obligational Markets and the Mechanics of Inflation, Be/ Jounal of Economics, Vol, 9, 1978, pp. 549-571.

Whitley, $\mathrm{R}$., The sciemific satus of management research as a practically oriented social science, Working-paper, Manchester Business School, 1983.

Whitley, R., The development of management studies as a fragmented adhockacy, Working. paper, Manchester Business School, 1984.

Williamson, O.E., Morkets and Hierarchies: Analysis and Antimust Impitacions, The Free Press, New York, 1975.

Williamson, O.E., Franchise Bidding for Natural Monopolies in General and with Respect to CATV, Bell Jounal of Economics, Vol. 7, 1976, pp. 73-104.

Willamson, O.E., The Economics of Organization: The Trancaction Cost Approneh, American Joumal of Socrology, Voll. 87, n. 3, 1981, pp. 548-577.

Williamson, O.E. en W.G. Ouch, The Markets and Hierarchics Program of Research: Origins, Implications, Prospects, in: A.H. wan de Ven en W.F. Joyoe, Perspecives on Orgamization Design and Behawor, Wiley, New York. 1981.

Williamson, O.E. M.L. Wackter en J.E. Marris, Understanding the Employment Relation: The Analysis of Idiosyncratic Exchange, Bell Jownal of Economics, Spring 1975, pp: 250.280.

Zwan, A. van der, Terug nat de werkelijkheid: een bethouwing over ondernemingsheloid en inarktstrategie, Econgmisch-Siatische Berichen, 20-4-1983, pp. 332-336. 